Article

\title{
Economic Value of Building a Firefighter Training Academy for Urban Disaster Management in Seoul, South Korea
}

\author{
Ju-Hee Kim, Hyo-Jin Kim and Seung-Hoon Yoo * (1) \\ Department of Energy Policy, Graduate School of Energy \& Environment, Seoul National University of Science \\ \& Technology, 232 Gongreung-Ro, Nowon-Gu, Seoul 01811, Korea; jhkim0508@seoultech.ac.kr (J.-H.K.); \\ hjinkim@seoultech.ac.kr (H.-J.K.) \\ * Correspondence: shyoo@seoultech.ac.kr; Tel.: +82-2-970-6802
}

Received: 25 October 2018; Accepted: 2 December 2018; Published: 5 December 2018

\begin{abstract}
The Seoul Metropolitan Government plans to build a new firefighter training academy (FTA) for urban disaster management. The Government needs information about its economic value to determine whether building a FTA is socially desirable. This paper aims to estimate the economic value of the FTA by applying a choice experiment (CE) method through a survey of firefighters who do on-site fire prevention activities in Seoul. The annual economic values of six training centers were estimated using the data from a total of 1658 firefighters who responded to the CE survey questionnaire, with a $1 \%$ statistical significance level. The economic value of the FTA amounts to KRW 10.04 billion (USD 8.80 million) annually. Given the 30-year operating period, the present value is KRW 129.86 billion, which can be seen as the economic benefit of building the FTA. The present value of the costs for the construction and operation of the FTA is KRW 54.66 billion (USD 48.30 million). As the benefits outweigh the costs, it can be concluded that it is socially profitable to build the FTA.
\end{abstract}

Keywords: firefighter training academy; urban disaster management; economic value; choice experiment; societal value

\section{Introduction}

Seoul, the capital of South Korea, is 605.21 square kilometers and the largest city in the country with a population of 10.09 million. In Seoul, there is the Han River, which is one kilometer wide, 116 mountains, many old wooden cultural assets that are vulnerable to fire, and nine subway lines with a total of 307 stations and a total length of $331.6 \mathrm{~km}$. The Seoul Metropolitan Government plans to build a new firefighter training academy (FTA) for urban disaster management and thus wants to learn about its economic value (EV) to determine whether building a FTA is socially desirable. The FTA will consist of six centers: an underground (railroad) complex accident response training center, a firefighting training center, a vehicle accident response training center, a chemical, biological and radiological terror response training center, a collapse search and rescue training center, and a wooden cultural properties fire response training center.

There are some difficulties in determining the methodology for estimating the EV of building the FTA. EV is defined as economic utility and also represent market value. First, it is difficult to find a good methodology for estimating the EV because there are no existing directly relevant case studies and only similar studies that evaluate the EV for buildings and facilities [1,2]. Second, although the construction and operation of the FTA reduces the damage caused by an urban disaster [3,4], it is very difficult to obtain a correlation equation that indicates how much damage will be diminished by the 
construction and operation of the FTA. In other words, the effects of the number of graduates of, or the total hours of training at, the FTA, on the rate of damage reduction should be identified mathematically, but the detailed structure itself is a kind of black box. It is difficult to obtain the damage reduction from the FTA directly. Third, it is difficult to estimate the EV of building and operating the FTA as it is a non-market good for Seoul citizens. That is, improving disaster management due to the FTA is a public good that is not traded in the market, and it is difficult to obtain information on its value. Therefore, special-designed methods should be used to estimate the EV of FTA.

For estimating the EV, a hypothetical market should be designed and engage potential customers, and then make hypothetical transactions. Potential demand for the FTA can be seen in two main cases. First, firefighters who utilize the FTA directly. Second, Seoul citizens who benefit from the FTA as an end-user who receives quality disaster management services from firefighters who utilize the FTA directly. If it is defined as the latter, a contingent valuation (CV) survey of randomly chosen Seoul citizens, by creating a hypothetical market, is needed to investigate the willingness to pay (WTP) for building and operating the FTA. The CV method is a frequently and widely applied stated preference valuation technique for assessing the value of non-market goods [1,2,5]. However, it can be difficult to answer the question of the WTP because ordinary Seoul citizens are not consumers directly using the FTA, and it is difficult to understand them well enough. Therefore, though the application of the CV method for measuring the EV of building the FTA may be possible, it may not be reasonable to use the derived values from the $\mathrm{CV}$ as the EV of building the FTA.

If possible, it may be accurate to investigate the views of firefighters who use the FTA directly and have a greater understanding of the FTA than Seoul citizens. However, it is not desirable to ask firefighters the question of WTP for establishing and operating the FTA. WTP is an economic concept, which means that individuals or households are willing to pay for consuming a good or a service by reducing other routine expenses under income constraint. The firefighters' WTP for building the FTA is not consistent with the economic theory, and thus cannot be interpreted as the EV of building the FTA. Therefore, a new approach, not a WTP, is necessary when conducting a survey of firefighters.

As an applicable concept in these cases, Keeny [6] proposed the societal value (SV) or fundamental value. SV is a decision analysis concept, which means the amount that society has to pay to get the proposed public good without restriction of personal income. Therefore, it is different from WTP, which means the amount a household or individual wants to pay for public goods under the restriction of personal income [7]. Gregory et al. [8] argued that the SV proposed by Keeny [6] might be preferable to WTP when measuring the EV of providing a public good. Moreover, SV refers to the various aspects of value that a particular good or project provides to society. Thus, they emphasized that the concept of SV is quite useful for a project with multiple attributes. For example, we need to assess the SV of an urban air pollution improvement project. In terms of the effects of the project, it has a variety of attributes such as reductions in the risks of mortality and morbidity, decreases in material damage and soiling damage, and abatement in damage to urban forests. If the SV of each attribute is available, the total SV of various alternatives for the project can be easily calculated. Interestingly, our target, the FTA, has six training centers. Baron [9] also pointed out that the WTP, which is commonly used in $\mathrm{CV}$ studies, may fail to properly reflect the underlying values, resulting in errors, and that the concept of SV should be used.

We think that the issue of SV versus WTP is not a matter of right or wrong, but a matter of philosophy or choice from a researcher's point of view. In other words, using the concept of SV is a good idea when WTP is appropriate from an economic theory point of view, but the elicitation of WTP is not appropriate since the derived WTP is not related to the nature of the good to be assessed. This study tries to estimate the EV of building the FTA by applying the concept of SV without applying the concept of WTP. This approach is judged to be justified by the practices of the literature.

For example, there are several case studies in which SVs are estimated by surveying people or experts who directly use a public good rather than ordinary citizens. Ubel et al. [10] revealed that the concept of SV could be used in a cost-benefit analysis or cost-effectiveness analysis for 
healthcare projects. Green [11] reviewed eight studies that estimated the SV for healthcare projects and found that the interviewees were students, experts in the field, politicians, and executive staff of the National Institute of Health. McDaniels and Roessler [12] conducted a survey of 28 undergraduate forest resources students at the University of British Columbia in Canada to estimate the SV of preserving Canadian forests. Kim et al. [7] induced the SV for an executive of a power company to assess environmental impacts in the South Korean power generation sector. Keeney et al. [13] conducted a survey of utility executives to assess the SV of improving the reliability of power supply. Keeney et al. [6] derived the SV related to sewage treatment facilities by conducting surveys with experts from sewage treatment authorities. There are many other similar cases. Therefore, investigating firefighters to extract the SV of building and operating the FTA is consistent with a number of preceding research cases. Furthermore, it is appropriate to target professional firefighters because Seoul citizens are not consumers directly using the FTA, it is difficult to understand the facilities of the FTA and understand the relationship between training in the FTA and improving disaster management.

Employing the concept of the SV of building the FTA, this article examines the EV of the FTA considering six attributes: an underground (railroad) complex accident response training center, a firefighting training center, a vehicle accident response training center, a chemical, biological and radiological terror response training center, a collapse search and rescue training center, and a wooden cultural properties fire response training center. The rest of this article consists of three sections. The methods and the models employed in the article are described in Section 2. The penultimate section presents and discusses the results. The conclusions are reported in the final section.

\section{Methodology}

\subsection{Method: $C E$}

Two techniques that have been widely employed for nonmarket good valuation in the literature are the choice experiment (CE) and CV method [14-20]. The CE method asks respondents to evaluate value trade-offs among some attributes and indirectly derives the SV they determine. Usually, the CV method is applied to a single-attribute good while the CE method is applied to a multi-attribute good. Therefore, the $\mathrm{CE}$ method is more suitable for valuing a multi-attribute good than the $\mathrm{CV}$ method [21-25]. The CE approach is theoretically grounded in the random utility maximization model. The model implies that if an individual chooses one alternative among several, the utility arising from the alternative is always greater than the utility arising from the other alternatives. Therefore, the application of the approach requires a survey of potential consumers. The CE method is useful for estimating the relative values of different attributes of an environmental and nonmarket good or new product [26-28].

In this study, the methodology for calculating the benefits of establishing a special firefighting facility is determined by the CE approach, which has been widely used to evaluate new products or services with multiple characteristics, like the FTA, in South Korea. In general, respondents are required to choose their preferred alternative out of several alternatives, which include a current status alternative, presented to them in the CE survey. Each alternative comprises several attributes of concern, including the price attribute. $\mathrm{CE}$ is a useful method for estimating the relative importance of several attributes of a good or service. The marginal SV (MSV) for increasing or decreasing the level of each attribute can be obtained by analyzing the data on respondents' choices and then interpreting or utilizing the results.

\subsection{Attributes and Choice Set}

As explained above, the FTA is made up of six centers: underground (railroad) complex accident response training center, firefighting training center, vehicle accident response training center, chemical, biological and radiological terror response training center, collapse search and rescue training center, and wooden cultural properties fire response training center. Figure 1 describes them. The descriptions 
and levels of seven attrributes including the SV per year as a price attribute are reported in Table 1 . The baseline for the FTA in this study is not to build all six centers.
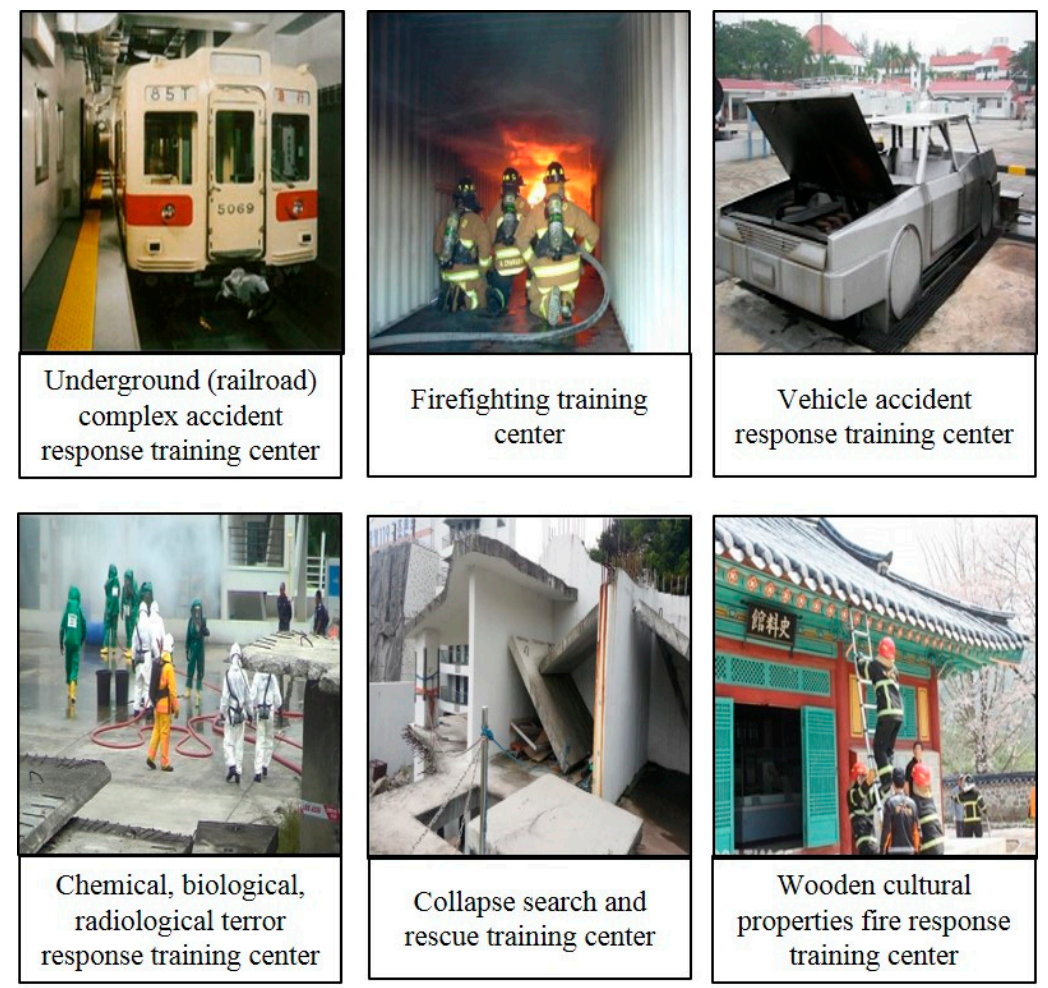

Figure 1. Six centers in proposed firefighter training academy.

Table 1. Description of chosen attributes.

\begin{tabular}{|c|c|c|}
\hline Attributes & Description & Levels \\
\hline $\begin{array}{l}\text { Underground (railroad) complex } \\
\text { accident response training center }\end{array}$ & $\begin{array}{l}\text { Perform training in preparation for various safety } \\
\text { accidents (e.g., elevator, escalator, screen door, etc.) } \\
\text { as well as fire }\end{array}$ & $\begin{array}{l}\text { Level 1: Not built \# } \\
\quad \text { Level 2: Built }\end{array}$ \\
\hline Firefighting training center & $\begin{array}{l}\text { Practice fire and prevent momentary ignition and } \\
\text { conduct adaptive training }\end{array}$ & $\begin{array}{l}\text { Level 1: Not built }{ }^{\#} \\
\text { Level 2: Built }\end{array}$ \\
\hline $\begin{array}{l}\text { Vehicle accident response training } \\
\text { center }\end{array}$ & $\begin{array}{l}\text { Using actual vehicles, train for traffic accident rescue } \\
\text { and train for skilled use of rescue equipment }\end{array}$ & $\begin{array}{l}\text { Level 1: Not built \# } \\
\text { Level 2: Built }\end{array}$ \\
\hline $\begin{array}{l}\text { Chemical, biological and radiological } \\
\text { terror response training center }\end{array}$ & $\begin{array}{l}\text { Conducts leakage response training at the hazardous } \\
\text { materials handling center }\end{array}$ & $\begin{array}{l}\text { Level 1: Not built \# } \\
\text { Level 2: Built }\end{array}$ \\
\hline $\begin{array}{l}\text { Collapse search and rescue training } \\
\text { center }\end{array}$ & $\begin{array}{l}\text { Explore survivors and conduct structural training in } \\
\text { the event of a collapse of buildings and structures }\end{array}$ & $\begin{array}{l}\text { Level 1: Not built \# } \\
\text { Level 2: Built }\end{array}$ \\
\hline $\begin{array}{l}\text { Wooden cultural properties fire } \\
\text { response training center }\end{array}$ & $\begin{array}{l}\text { Learn how to suppress and save wooden cultural } \\
\text { assets in case of fire }\end{array}$ & $\begin{array}{l}\text { Level 1: Not built \# } \\
\text { Level 2: Built }\end{array}$ \\
\hline Price $^{a}$ & $\begin{array}{l}\text { Annual societal value for the construction and } \\
\text { operation of the firefighter training academy, which } \\
\text { consists of six centers (Unit: One hundred million } \\
\text { Korean won) }\end{array}$ & $\begin{array}{l}\text { Level 1: } 0^{\#} \\
\text { Level 2: } 1 \\
\text { Level 3: } 5 \\
\text { Level 4: } 10 \\
\text { Level 5: } 20\end{array}$ \\
\hline
\end{tabular}

Notes: ${ }^{\#}$ indicates the current level of each attribute. ${ }^{a}$ The unit is Korean won. At the time of the survey, USD 1.0 was approximately equal to KRW 1145.

The number of possible alternatives generated from Table 1 amounts to $256(=2 \times 2 \times 2 \times 2 \times 2 \times$ $2 \times 4)$. However, it is not necessary or appropriate to present all these alternatives to the respondents because of the respondents' bounded rationality and time/cost constraints. Therefore, a main effect orthogonal design was applied to give only sixteen alternatives [29], which are reported in Table 2. They were randomly mixed, and from these eight choice sets were generated. Each choice set is made 
up of two alternatives and the current status alternative. Each interviewee was presented with eight choice sets and reported eight responses to the provided questions that indicated which alternatives were the most preferred among the three alternatives in each choice set. Figure A1 is an example of the choice set we presented to the respondents.

Table 2. Sixteen chosen alternatives.

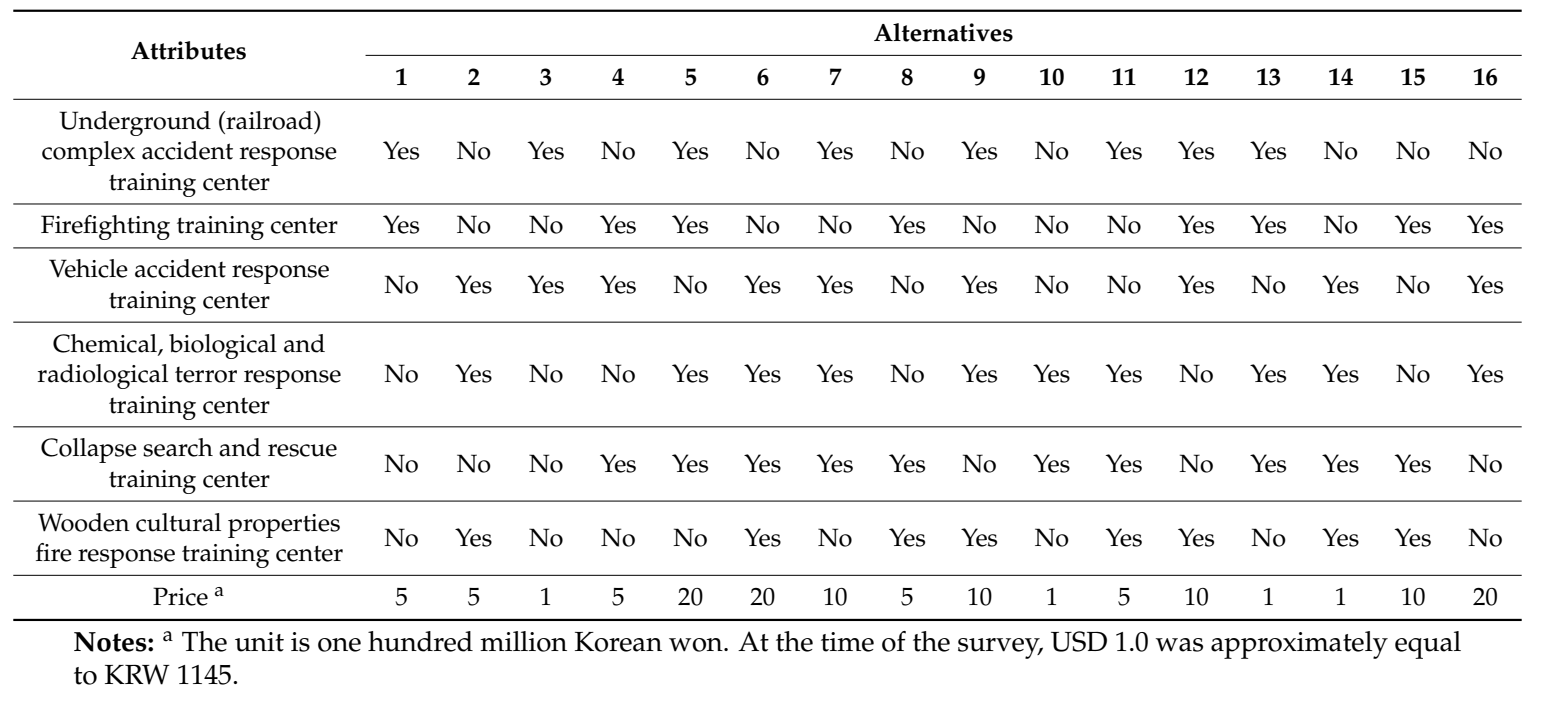

\subsection{Survey Instrument and Method}

There are three parts in the survey instrument. Several questions about the FTA that check respondents' perceptions make up the first part before the CE survey on the FTA begins in earnest. The respondents were asked about the need for the FTA, the experience and necessity of each detailed training facility, the adequacy of the construction period, and whether it could help in actual situations. To facilitate the respondents' understanding, a description of the features and effects of the FTA was provided, along with color photographs, in this section. Such work not only relieves respondents of the burden of a fully fledged survey but also provides significant statistical data in itself. Explanations about the attributes and questions concerning the value trade-off work, which are conventionally required in a CE survey, are presented in the second part. The third part contains questions about the respondents' socio-economic information.

A CE survey of 1658 firefighters was undertaken by a professional polling firm through internet-based interviews during February 2017. The main part of the survey questionnaire in this study is given in Appendix A. The survey was conducted by asking respondents whether they would like to participate in the survey by e-mail first and then accessing the web and responding to the survey. A survey of a total of 7000 firefighters in Seoul showed that 2239 responded to the survey, with a total of 1658 effective responses excluding invalid responses. Each interviewee provided eight observations from eight choice sets. In other words, each interviewee was presented with eight choice sets and reported eight responses to the provided questions. Thus, the survey yielded 13,264 $(=1658 \times 8)$ usable items of data.

Prior to this CE survey, the price attributes of the FTA were set at four levels by conducting a literature survey and from consultation with experts in the fire sector. The price is the SV, which means the amount that society, not the individual, should pay to build and operate the FTA to improve the fire safety of Seoul citizens. Regarding the SV of building the FTA, firefighters were told to "please note that the SV of building the FTA refers to the amount that society must pay to establish and operate the FTA to protect the safety of Seoul citizens. The purpose of this survey is to know the SV of building the FTA you are assessing. In this survey, we would like to ask you about the SV of improving the safety 
of Seoul citizens by building the FTA specialized in the disaster patterns of Seoul City and training and educating them at the FTA".

\subsection{Utility Function}

The levels of the six attributes and price are defined as $X_{t}$, where $t=1,2,3,4,5,6, p$. Furthermore, we consider the alternative-specific constant, $A S C$, which is defined as one if the interviewee chooses the current status alternative from among the three alternatives and zero otherwise. Let $V_{j l}$ be the utility for an interviewee $j$ who chooses alternative $l$. The utility function is formulated as:

$$
\begin{aligned}
V_{j l}= & W_{j l}\left(X_{j l}, T_{j}\right)+\varepsilon_{j l} \\
= & A S C_{j}+\beta_{1} X_{1, j l}+\beta_{2} X_{2, j l}+\beta_{3} X_{3, j l}+\beta_{4} X_{5, j l}+\beta_{4} X_{5, j l}+\beta_{6} X_{6, j l} \\
& \quad+\beta_{p} X_{p, j l}+\varepsilon_{j l}
\end{aligned}
$$

where $W_{j l}$ and $\varepsilon_{j l}$ are the deterministic and stochastic parts of the utility function, respectively; $X_{j l}$ is a vector containing the levels of the attributes for alternative $l$ given to respondent $j ; T_{j}$ is respondent $j$ 's characteristics, such as ASC; and the $\beta^{\prime}$ s are the coefficients that correspond to each attribute.

Omitting $j l$ for simplicity, we can apply Roy's identity to Equation (1) and derive the MSV estimate as:

$$
\begin{aligned}
& M S V_{X_{1}}=-\left(\partial W / \partial X_{1}\right) /\left(\partial W / \partial X_{p}\right)=-\beta_{1} / \beta_{p} \\
& M S V_{X_{2}}=-\left(\partial W / \partial X_{2}\right) /\left(\partial W / \partial X_{p}\right)=-\beta_{2} / \beta_{p} \\
& M S V_{X_{3}}=-\left(\partial W / \partial X_{3}\right) /\left(\partial W / \partial X_{p}\right)=-\beta_{3} / \beta_{p} \\
& M S V_{X_{4}}=-\left(\partial W / \partial X_{4}\right) /\left(\partial W / \partial X_{p}\right)=-\beta_{4} / \beta_{p} \\
& M S V_{X_{5}}=-\left(\partial W / \partial X_{5}\right) /\left(\partial W / \partial X_{p}\right)=-\beta_{5} / \beta_{p} \\
& M S V_{X_{6}}=-\left(\partial W / \partial X_{6}\right) /\left(\partial W / \partial X_{p}\right)=-\beta_{6} / \beta_{p}
\end{aligned}
$$

\subsection{Obtaining the Utility Function}

Estimating the utility function implies estimating $\beta$ 's. The multinomial logit (MNL) model suggested by McFadden [30] has been most widely applied to obtain $\beta$ in the literature. However, the MNL model inevitably assumes independence from irrelevant alternatives. Although the assumption seems to be somewhat restrictive, it has the advantage of enabling us to specify the log-likelihood function as a closed form. Thus, if the assumption is met, we can easily tackle the $\mathrm{CE}$ data. Let $J$ be the number of interviewees and $I_{j l}$ be a dummy variable that is defined as one if interviewee $j$ selects alternative $l$; otherwise, $I_{j l}$ is zero. The log-likelihood function for our MNL model is:

$$
I n L=\sum_{j-1}^{J} \operatorname{In}\left[\frac{\prod_{k-1}^{3}\left(\exp \left(W_{j k}\right)\right)^{I_{j k}}}{\sum_{n-1}^{3} \exp \left(W_{j n}\right)}\right]
$$

\section{Results}

\subsection{Estimation Results}

As mentioned above, a professional polling firm implemented a nationwide CE survey of 1658 respondents through internet-based interviews during February 2017. The results of estimating the MNL model are reported in Table 3. To understand the average impact of the utility of elements not observed in the model, we introduced the ASC. Interestingly, the coefficient estimates for all attributes have positive signs. As the marginal level of each attribute from the baseline state rises, the utility for the firefighters increases. The estimated coefficient for the price is negative. This implies that, as the price increases, the utility decreases. This result is quite reasonable, given that the price contributes negatively to the utility. 
Table 3. Estimation results of the model.

\begin{tabular}{cc}
\hline Variables $^{\text {a }}$ & Estimates $(t$-Values) \\
\hline ASC $^{\mathrm{b}}$ & $0.6220(6.26)^{\mathrm{c}}$ \\
Underground (railroad) complex accident response training center & $1.0092(27.90)^{\mathrm{c}}$ \\
Firefighting training center & $1.7964(28.72)^{\mathrm{c}}$ \\
Vehicle accident response training center & $0.9648(18.61)^{\mathrm{c}}$ \\
Chemical, biological and radiological terror response training center & $1.2354(17.42)^{\mathrm{c}}$ \\
Collapse search and rescue training center & $0.4423(10.10)^{\mathrm{c}}$ \\
Wooden cultural properties fire response training center & $0.7014(16.97)^{\mathrm{c}}$ \\
Price (Unit: One hundred million Korean won) & $-0.0613(-7.76)^{\mathrm{c}}$ \\
Number of observations & 11,903 \\
Log-likelihood & -8910.19 \\
Wald statistic ( $p$-value) & $66.23(0.000)$ \\
\hline
\end{tabular}

Notes: ${ }^{\text {a }}$ The variables are defined in Table $1 .{ }^{\mathrm{b}}$ ASC refers to alternative-specific constant that represents dummy for the respondent's choosing current status. ${ }^{\mathrm{c}}$ Indicates statistical significance at the $1 \%$ level.

\subsection{MSV Estimates for Each Attribute}

Finally, the MSV for the level of each attribute can be derived by employing Equation (2). Table 4 provides the results of the MSV estimations and their confidence intervals calculated using Krinsky and Robb's [29] method. The firefighters' MSV estimates for an underground (railroad) complex accident response training center, a firefighting training center, a vehicle accident response training center, a chemical, biological and radiological terror response training center, a collapse search and rescue training center, and a wooden cultural properties fire response training center are reflected as increases of KRW 1.65 billion (USD 1.44 million), KRW 2.93 billion (USD 2.56 million), KRW 1.58 billion (USD 1.38 million), KRW 2.02 billion (USD 1.76 million), KRW 0.72 billion (USD 0.63 million), and KRW 1.15 billion (USD 1.00 million), respectively, per year. These values are interpreted as the EV of building FTA in Seoul.

Table 4. Estimates of the marginal societal value (MSV).

\begin{tabular}{|c|c|c|c|}
\hline & \multicolumn{3}{|c|}{ MSV per Year } \\
\hline & Estimates & $t$-Values & 95\% Confidence Intervals \\
\hline $\begin{array}{l}\text { Underground (railroad) complex accident } \\
\text { response training center }\end{array}$ & $\begin{array}{l}\text { KRW } 1.65 \text { billion }{ }^{\#} \\
\text { (USD } 1.44 \text { million) }\end{array}$ & 8.14 & $\begin{array}{l}\text { KRW } 1.64 \text { to } 1.65 \text { billion } \\
\text { (USD } 1.44 \text { to } 1.44 \text { million) }\end{array}$ \\
\hline Firefighting training center & $\begin{array}{l}\text { KRW } 2.93 \text { billion \# } \\
\text { (USD } 2.56 \text { million) }\end{array}$ & 9.66 & $\begin{array}{l}\text { KRW } 2.93 \text { to } 2.94 \text { billion } \\
\text { (USD } 2.56 \text { to } 2.56 \text { million) }\end{array}$ \\
\hline Vehicle accident response training center & $\begin{array}{l}\text { KRW } 1.58 \text { billion \# } \\
\text { (USD } 1.38 \text { million) }\end{array}$ & 10.32 & $\begin{array}{l}\text { KRW } 1.57 \text { to } 1.58 \text { billion } \\
\text { (USD } 1.37 \text { to } 1.38 \text { million) }\end{array}$ \\
\hline $\begin{array}{l}\text { Chemical, biological and radiological terror } \\
\text { response training center }\end{array}$ & $\begin{array}{l}\text { KRW } 2.02 \text { billion \# } \\
\text { (USD } 1.76 \text { million) }\end{array}$ & 10.60 & $\begin{array}{l}\text { KRW } 2.01 \text { to } 2.02 \text { billion } \\
\text { (USD } 1.76 \text { to } 1.76 \text { million) }\end{array}$ \\
\hline Collapse search and rescue training center & $\begin{array}{l}\text { KRW } 0.72 \text { billion \# } \\
\text { (USD } 0.63 \text { million) }\end{array}$ & 5.89 & $\begin{array}{l}\text { KRW } 0.72 \text { to } 0.72 \text { billion } \\
\text { (USD } 0.63 \text { to } 0.63 \text { million) }\end{array}$ \\
\hline $\begin{array}{l}\text { Wooden cultural properties fire response } \\
\text { training center }\end{array}$ & $\begin{array}{l}\text { KRW } 1.15 \text { billion \# } \\
\text { (USD } 1.00 \text { million) }\end{array}$ & 8.32 & $\begin{array}{l}\text { KRW } 1.14 \text { to } 1.15 \text { billion } \\
\text { (USD } 1.00 \text { to } 1.00 \text { million) }\end{array}$ \\
\hline
\end{tabular}

\footnotetext{
Notes: \# implies statistical meaningfulness at the 1\% level. USD 1.0 was approximately equal to KRW 1145 at the time of the survey.
}

\subsection{Discussion of the Results}

In this study, a CE was applied using the concept of SV for the purpose of estimating the EV of the FTA. In other words, we tried to combine the concept of SV with the CE technique. Some interesting findings emerge from the results. The SV of the firefighting training center was the highest of the six centers. On the other hand, the SV of the collapse search and rescue training center was the lowest. The former is about four times more valuable than the latter. The SVs of the remaining four 
centers are in the order of the chemical, biological and radiological terror response training center, the underground (railroad) complex accident response training center, the vehicle accident response training center, and the wooden cultural properties fire response training center. Although all six facilities are important, if the budget is limited, consideration may be given to the construction of top-ranked centers before bottom-ranked ones. Using the information presented in Table 4, it is easy to identify the relative value that firefighters in Seoul give to each center. As such, although the SV of each center has been shown quantitatively through this study, limitations of this study are that the degree of disaster management improvement or damage reduction through the construction of the FTA cannot be quantitatively determined.

The framework of this study can be used to estimate the construction benefits of various facilities other than the FTA that was investigated here. For example, when estimating the SV of constructing a public library or museum, the framework may be similarly applied using a CE survey of the citizens or stakeholders. Libraries have a number of attributes, such as the number of books they have, user accessibility, whether they operate a cyber library, whether they have the latest data, and whether they have rare materials. In the same way, museums have a number of attributes, such as the number of artifacts they have, whether they provide experience programs, visitor accessibility, and whether to hold special exhibitions. In these circumstances, the application of this framework not only provides EV for individual attributes of a facility, but also gives the total value of a facility.

Using the results presented in Table 4, it is easy to elicit the EV for alternatives where only some centers are built out of the six centers. As an illustration, the results of calculating the EV for which the firefighters assess a few hypothetical scenarios for building the FTA are shown in Table 5 . For example, the EV of the second scenario of building the three centers of the firefighting training center, the chemical, biological and radiological terror response training center, and the wooden cultural properties fire response training center is computed as KRW 6.10 billion (USD 5.32 million) per year. Similarly, the EV of building all six centers is calculated to be KRW 10.04 billion (USD 8.77 million).

Table 5. Hypothetical scenarios for building the firefighter training academy.

\begin{tabular}{|c|c|c|c|}
\hline & Scenario A & Scenario B & Scenario C \\
\hline $\begin{array}{l}\text { Underground (railroad) complex accident } \\
\text { response training center }\end{array}$ & Yes & No & Yes \\
\hline Firefighting training center & No & Yes & Yes \\
\hline Vehicle accident response training center & Yes & No & Yes \\
\hline $\begin{array}{l}\text { Chemical, biological and radiological terror } \\
\text { response training center }\end{array}$ & No & Yes & Yes \\
\hline Collapse search and rescue training center & Yes & No & Yes \\
\hline $\begin{array}{l}\text { Wooden cultural properties fire response } \\
\text { training center }\end{array}$ & No & Yes & Yes \\
\hline Economic value per year & $\begin{array}{l}\text { KRW } 3.95 \text { billion } \\
\text { (USD } 3.45 \text { million) }\end{array}$ & $\begin{array}{l}\text { KRW } 6.10 \text { billion } \\
\text { (USD } 5.32 \text { million) }\end{array}$ & $\begin{array}{l}\text { KRW } 10.04 \text { billion } \\
\text { (USD } 8.77 \text { million) }\end{array}$ \\
\hline
\end{tabular}

Note: USD 1.0 was approximately equal to KRW 1145 at the time of the survey.

\section{Conclusions}

The Seoul Metropolitan Government has planned to build a new FTA for urban disaster management. Therefore, the Government wants to learn about its economic value to determine whether building the FTA is socially desirable. This is because the investment to build the FTA can be justified only when the benefits of building the FTA should be greater than the costs of building the FTA. The FTA will consist of six centers: an underground (railroad) complex accident response training center, a firefighting training center, a vehicle accident response training center, a chemical, biological and radiological terror response training center, a collapse search and rescue training center, 
and a wooden cultural properties fire response training center. This paper estimated the EV of the FTA by applying the CE method through a survey of firefighters who do on-site fire prevention activities in Seoul.

We think that this research is relevant from both a policy and research perspective. First, from a policy perspective, it derived and presented a value for the economic benefit of building the FTA, which is the information that the Government desperately needs. This study found that the annual economic benefit amounted to KRW 10.04 billion (USD 8.77 million). The Government will use this value as important information when building the FTA. In particular, because we have estimated the EV of six centers separately, we can easily derive information about the EV of building only some centers.

Second, from a research perspective, this study contributed to CE literature by applying the CE technique, one of the economic valuation techniques, to calculate the economic benefits of building the FTA in Seoul. In particular, the implications of this study will be even more beneficial in that it is the first study in the world that requires information on the economic benefits of building the FTA. Of course, the framework of this study needs to be expanded further. For example, some topics such as comparing our results with the EV derived for other regions in South Korea and applying the framework of this study to other countries for comparison will be fruitful. These follow-up tasks will especially contribute to preparing customized plans for urban disaster management by helping to more accurately estimate the EV of building the FTA.

Author Contributions: All the authors made important contributions to this paper. J.-H.K. worked to draft and refine the questionnaire for the CE application to collect data, and created more than half of the manuscript; H.-J.K. carried out the literature review and wrote the remaining part of the manuscript; and S.-H.Y. was responsible for designing and applying the economic and statistical models needed for obtaining the results.

Acknowledgments: This study was supported by the Research Program funded by the SeoulTech (Seoul National University of Science and Technology).

Conflicts of Interest: The authors declare no conflicts of interest.

\section{Appendix A. Main Part of the Survey Questionnaire}

\section{Appendix A.1. Questions about Socio-Economic Characteristics}

The interviewees were asked to respond to their socio-economic characteristics such as the gender of the individual, the number of family members, the level of education, and the monthly income per household (before tax deduction). Questions about the number of family and income were open-ended questions, and the question about the level of education was as follows:

Table A1. Q1. Please check with $\sqrt{ }$ your education level in years.

\begin{tabular}{ccccccc}
\hline $\begin{array}{c}\text { Education } \\
\text { Level }\end{array}$ & Uneducated & $\begin{array}{c}\text { Elementary } \\
\text { School }\end{array}$ & $\begin{array}{c}\text { Middle } \\
\text { School }\end{array}$ & $\begin{array}{c}\text { High } \\
\text { School }\end{array}$ & University & $\begin{array}{c}\text { Graduate } \\
\text { School }\end{array}$ \\
\hline $\begin{array}{c}\text { Education } \\
\text { level in years }\end{array}$ & 0 & 123456 & 789 & 101112 & 13141516 & 17181920 \\
\hline
\end{tabular}

Appendix A.2. Questions about Marginal Societal Value

Type A. Q1. Check with $\sqrt{ }$ the only available alternative that you prefer among Alternative A, B or the current status. 


\begin{tabular}{|c|c|c|c|}
\hline & Alternative A & Alternative B & Alternative $\mathrm{C}$ \\
\hline $\begin{array}{l}\text { Underground (railroad) complex } \\
\text { accident response training center }\end{array}$ & Yes & No & No \\
\hline Firefighting training center & No & Yes & No \\
\hline $\begin{array}{l}\text { Vehicle accident response training } \\
\text { center }\end{array}$ & Yes & Yes & No \\
\hline $\begin{array}{l}\text { Chemical, biological and } \\
\text { radiological terror response } \\
\text { training center }\end{array}$ & No & No & No \\
\hline $\begin{array}{l}\text { Collapse search and rescue } \\
\text { training center }\end{array}$ & No & Yes & No \\
\hline $\begin{array}{l}\text { Wooden cultural properties fire } \\
\text { response training center }\end{array}$ & No & No & No \\
\hline Price & 1 & 5 & 0 \\
\hline & $\begin{array}{c}\square \\
\text { Alternative A }\end{array}$ & $\begin{array}{c}\square \\
\text { Alternative B }\end{array}$ & $\begin{array}{c}\square \\
\text { Current status }\end{array}$ \\
\hline
\end{tabular}

Figure A1. A sample choice set used in this study.

\section{References}

1. Kwak, S.Y.; Yoo, S.H. The public value of a national library: Results of a contingent valuation survey. J. Librariansh. Inf. Sci. 2012, 44, 263-271. [CrossRef]

2. Jin, S.J.; Lim, S.Y.; Yoo, S.H. The public value of building large oil spill response vessels in Korea. Mar. Policy 2018, 88, 242-247. [CrossRef]

3. Dennison, K.J.; Mullineaux, D.R.; Yates, J.W.; Abel, M.G. The effect of fatigue and training status on firefighter performance. J. Strength Cond. Res. 2012, 26, 1101-1109. [CrossRef] [PubMed]

4. Pawlak, R.; Clasey, J.L.; Palmer, T.; Symons, T.B.; Abel, M.G. The effect of a novel tactical training program on physical fitness and occupational performance in firefighters. J. Strength Cond. Res. 2015, 29, 578-588. [CrossRef] [PubMed]

5. Mitchell, R.C.; Carson, R.T. Using Surveys to Value Public Goods: The Contingent Valuation Method; Resources for the Future Press: Washington, DC, USA, 1989.

6. Keeney, R.L. Value-Focused Thinking; Harvard University Press: Cambridge, MA, USA, 1996.

7. Kim, T.Y.; Kwak, S.J.; Yoo, S.H. Applying multi-attribute utility theory to decision making in environmental planning: A case study of the electric utility in Korea. J. Environ. Plan. Manag. 1998, 41, 597-609. [CrossRef]

8. Gregory, R.; Lichtenstein, S.; Slovic, P. Valuing environmental resources: A constructive approach. J. Risk Uncertain. 1993, 7, 177-197. [CrossRef]

9. Baron, I. Rationality and invariance: Response to Schuman. In The Contingent Valuation of Environmental Resources; Bjornstad, D.J., Kahn, J.R., Eds.; Edward Elgar: Cheltenham, UK, 1996.

10. Ubel, P.A.; Richardson, J.; Menzel, P. Societal value, the person trade-off, and the dilemma of whose values to measure for cost-effectiveness analysis. Health Econ. 2000, 10, 233-243. [CrossRef]

11. Green, C. On the societal value of health care: What do we know about the person trade-off technique? Health Econ. 2001, 10, 233-243. [CrossRef]

12. McDaniels, T.L.; Roessler, C. Multiattribute elicitation of wilderness preservation benefits: A constructive approach. Ecol. Econ. 1998, 27, 299-312. [CrossRef]

13. Keeney, R.L.; McDaniels, T.; Swoveland, C. Evaluating the benefits of electrical system reliability improvements at British Columbia Hydro. Oper. Res. 1995, 43, 933-947. [CrossRef] 
14. Min, S.H.; Lim, S.Y.; Yoo, S.H. Consumer's willingness to pay a premium for eco-labeled LED TVs in Korea: A contingent valuation study. Sustainability 2017, 9, 814.

15. Park, S.Y.; Lim, S.Y.; Yoo, S.H. The economic value of the national meteorological service in the Korean household sector: A contingent valuation study. Sustainability 2016, 8, 834. [CrossRef]

16. Lim, S.Y.; Kim, H.Y.; Yoo, S.H. Public willingness to pay for transforming Jogyesa Buddhist temple in Seoul, Korea into a cultural tourism resource. Sustainability 2016, 8, 900. [CrossRef]

17. Kim, H.Y.; Park, S.Y.; Yoo, S.H. Public acceptability of introducing a biogas mandate in Korea: A contingent valuation study. Sustainability 2016, 8, 1087. [CrossRef]

18. Wang, J.; Ge, J.; Ma, Y. Urban Chinese consumers' willingness to pay for pork with certified labels: A discrete choice experiment. Sustainability 2018, 10, 603. [CrossRef]

19. Yang, H.J.; Lim, S.Y.; Yoo, S.H. The environmental costs of photovoltaic power plants in South Korea: A choice experiment study. Sustainability 2017, 9, 1773. [CrossRef]

20. Vanstockem, J.; Vranken, L.; Bleys, B.; Somers, B.; Hermy, M. Do looks matter? A case study on extensive green roofs using discrete choice experiments. Sustainability 2018, 10, 309. [CrossRef]

21. Madden, G.; Simpson, M. Residential broadband subscription demand: An econometric analysis of Australian choice experiment data. Appl. Econ. 1997, 219, 1073-1078. [CrossRef]

22. Baarsma, B.E. The valuation of the Ijmeer nature reserve using conjoint analysis. Environ. Resour. Econ. 2003, 25, 343-356. [CrossRef]

23. Yoo, S.H.; Kwak, S.J.; Lee, J.S. Using a choice experiment to measure the environmental costs of air pollution impacts in Seoul. J. Environ. Manag. 2008, 86, 308-318. [CrossRef]

24. Banfi, S.; Filippini, M.; Horehájová, A. using a choice experiment to estimate the benefits of a reduction of externalities in urban areas with special focus on electrosmog. Appl. Econ. 2012, 44, 387-397. [CrossRef]

25. Tarfasa, S.; Brouwer, R. Estimation of the public benefits of urban water supply improvements in Ethiopia: A choice experiment. Appl. Econ. 2013, 45, 1099-1108. [CrossRef]

26. Garrod, G.D.; Willis, K.G. The non-use benefits of enhancing forest biodiversity: A contingent ranking study. Ecol. Econ. 1997, 21, 45-61. [CrossRef]

27. Ida, T.; Kinoshita, S.; Sato, M. Conjoint analysis of demand for IP telephony: The case of Japan. Appl. Econ. 2008, 40, 1279-1287. [CrossRef]

28. Ida, T. Beyond mobile number portability: Measuring consumer preferences for service portability in Japan's mobile phone market. Appl. Econ. 2012, 44, 3357-3369. [CrossRef]

29. Krinsky, I.; Robb, A.L. On approximating the statistical properties of elasticities. Rev. Econ. Stat. 1986, 68, 715-719. [CrossRef]

30. McFadden, D. Conditional logit analysis of qualitative choice behavior in frontiers in econometrics. In Frontiers in Econometrics; Zarembka, P., Ed.; Academic Press: New York, NY, USA, 1973; pp. 105-142. 